\title{
The Analysis of the Relationship between the Values under IFRS and under GCAS: An Exploratory Study on Moroccan Financial Market
}

\author{
Anass Cherti (Corresponding author) \\ Department of Management \\ Faculty of Legal, Economic, and Social Sciences, Tangier, Morocco \\ E-mail: cherti.anass@gmail.com \\ Houria Zaam \\ Department of Management \\ Faculty of Legal, Economic, and Social Sciences, Tetouan, Morocco
}

Received: September 3, 2017 Accepted: September 15, 2017 Published: November 12, 2017

doi:10.5296/ijafr.v7i2.11799 URL: https://doi.org/10.5296/ijafr.v7i2.11799

\begin{abstract}
Until the end of the 1980s, the activity of accounting standardization was strictly national for tax and legal reasons. This conception or logic was revised in the last quarter of the twentieth century following the globalization of the economy and the intensification of the international market/stock exchanges. Indeed, the multitude of accounting standards urged investors to spend an enormous amount of time understanding them before analyzing the economic situation of the countries in which they wanted to invest. Several organizations were therefore set up to develop international accounting standards.

The purpose of this article is to present the results of an empirical study using companies listed on the Casablanca Stock Exchanges (CSE), to measure the relationship between the values under International Financial Reporting Standards (IFRS) and those under the General Code of Accounting Standardization (GCAS) on the Moroccan financial market.

The results show that the values of the accounting and financial information under the international reference "IFRS" are in common evolution with the values of accounting and financial information under the national reference "GCAS".
\end{abstract}

Keywords: international financial reporting standards, general standardization code of Morocco, correlation, financial and accounting information 
In order to verify our hypothesis there is a strong relationship between the accounting and financial variables under the international reference IFRS with those under the national reference, using an econometric demonstration(Gavard-Perret et al., 2012), a new matrix was created in which columns represent the types of accounting and financial information under IFRS and GCAS (after \& before IFRS implementation). Thus, the two-by-two Pearson's correlation results are shown in Tables 1,2 and 3. These tables show that, with the exception of the variable "general liquidity ratio", all variables are well correlated in pairs for both IFRS and GCAS. These correlations are at least statistically significant at 0.05 risk level.

To further digging in our data and to strength our investigation, the quality of these relationships were analysed. To this end, the entire sample has been decomposed into variables (Cherti and Zaam, 2016) and each variable is analyzed separately "see figures: 1 to $5 "$.

The correlation coefficient(Hallouët, 2016) is a statistical measure that makes it possible to assess the relationships between three types of statistical data sets, the GCAS before the adoption of IFRS, the GCAS after the adoption of IFRS, and IFRS(Ahsina et al., 2014). The correlation coefficient is between 1 and -1 and it is generally considered that if its absolute value is near to 1 there is a strong relationship between variables. If this value is positive, the two series evolve in the same direction, and if it is negative, then they evolve in the opposite direction. We should bear in mind that the presence of a strong (positive or negative) correlation does not proof any causality link(Palea, 2013), because the two sets of data can be influenced jointly by a third factor.

After conducting this analysis, the GCAS variables before and after the adoption of IFRS are correlated (Tables 1 to 3 ).

The correlation tables present the overall relationship between GCAS and IFRS, however this picture hides different views if downscaled into sectors. Indeed, except for a few sectors (Figures 1 to 4), in view of their specificities for certain variables and periods, their influence is remarkable after the adoption of IFRS (Cherti and Zaam, 2016), but generally with the opening of Moroccan accounting to the world (Haoudi, 2015), the reaction was positive and the developments were common (Zehri and Chouaibi, 2013) in almost the majority of sectors and variables of the Moroccan market.

To reducing the factors influencing our study and clearly visualizing the main common components that group different variables, we refer to the Principal Component Analysis (PCA) which is one of the most widely used methods to analyze multivariate data(Raymond-Alain, 2017). The purpose is to visualize the relationship between variables, and possibly limiting the number of components.

After the correlation matrices, the graphical representations between each variable, each sector and each referential and after the PCA which groups the different graphs to visualize the reconciliation (grouping / classification) of these different variables, we recall the hierarchical analysis (Figure 5) to measure the mean distances between the different classes of variables, which confirmed the results of the PCA. 


\section{Ml Macrothink \\ International Journal of Accounting and Financial Reporting \\ ISSN 2162-3082 \\ 2017, Vol. 7, No. 2}

Table 1. Correlation between the variables of GCAS2007-2011 and GCAS 2012-2016

\begin{tabular}{|c|c|c|c|c|c|c|c|c|c|c|c|c|c|c|}
\hline \multicolumn{2}{|c|}{$\begin{array}{l}\text { GCAS2007-2011 } \\
\text { vs. } \\
\text { GCAS2012-2016 }\end{array}$} & $\begin{array}{l}\text { Fixed } \\
\text { assets } \\
2012- \\
2016 \\
\end{array}$ & $\begin{array}{c}\text { Current } \\
\text { assets } \\
2012-20 \\
16 \\
\end{array}$ & $\begin{array}{c}\text { Treasury } \\
2012-20 \\
16\end{array}$ & $\begin{array}{c}\text { Total } \\
\text { assets } \\
2012-2 \\
016 \\
\end{array}$ & $\begin{array}{l}\text { Permanent } \\
\text { funding } \\
2012-2016\end{array}$ & $\begin{array}{c}\text { Current } \\
\text { liabilities } \\
2012-20 \\
16 \\
\end{array}$ & $\begin{array}{l}\text { Treasury } \\
2012-20 \\
16\end{array}$ & $\begin{array}{c}\text { Total } \\
\text { liabilities } \\
2012-20 \\
16 \\
\end{array}$ & $\begin{array}{c}\text { Net } \\
\text { profit } \\
2012-20 \\
16 \\
\end{array}$ & $\begin{array}{c}\text { Debt } \\
\text { ratio } \\
2012-20 \\
16 \\
\end{array}$ & $\begin{array}{c}\text { Current } \\
\text { ratio } \\
2012-201 \\
6 \\
\end{array}$ & $\begin{array}{c}\text { Investor } \\
\text { Investment } \\
\text { Ratio2012- } \\
2016 \\
\end{array}$ & $\begin{array}{c}\text { Financial } \\
\text { profitability } \\
2012-2016\end{array}$ \\
\hline \multirow[t]{2}{*}{$\begin{array}{l}\text { Fixed } \\
\text { assets_GCAS }\end{array}$} & $\begin{array}{l}\text { Correlation } \\
\text { of Pearson }\end{array}$ & $\begin{array}{r}989^{*} \\
*\end{array}$ & ,168 &, $550^{* *}$ &, $764^{* *}$ &, $982^{* *}$ & ,202 &, $412^{* *}$ &, $764^{* *}$ &, $728^{* *}$ &,- 165 &, $489^{* *}$ &,- 056 &, $456^{* *}$ \\
\hline & Sig. & ,000 & ,269 & ,000 & ,000 & ,000 &, 184 & ,005 & ,000 & ,000 & ,278 & ,001 &, 714 & ,002 \\
\hline \multirow[t]{2}{*}{$\begin{array}{l}\text { Current } \\
\text { assets_GCAS }\end{array}$} & $\begin{array}{l}\text { Correlation } \\
\text { of Pearson }\end{array}$ & ,091 &, $990 * *$ & , 183 &, $708^{* *}$ & ,094 &, $989^{* *}$ &,- 075 &, $708^{* *}$ & ,044 &, $845^{* *}$ &, $515^{* *}$ & ,001 &,- 048 \\
\hline & Sig. & ,551 & ,000 & ,230 & ,000 & ,539 & ,000 & ,624 & ,000 &, 772 & ,000 & ,000 & ,996 & ,754 \\
\hline \multirow[t]{2}{*}{$\begin{array}{l}\text { Treasury } \\
\text { _GCAS }\end{array}$} & $\begin{array}{l}\text { Correlation } \\
\text { of Pearson }\end{array}$ & $\begin{array}{r}497^{*} \\
* \\
\end{array}$ & ,245 & ,936** &, $528^{* *}$ &, $463^{* *}$ & ,286 &, $547^{* *}$ &, $526^{* *}$ &, $908^{* *}$ & , 142 &, $341^{*}$ &,- 186 &, $860^{* *}$ \\
\hline & Sig. & ,001 & , 105 & ,000 & , 000 & ,001 & ,057 & , 000 & ,000 & ,000 &, 351 &, 022 & ,222 & ,000 \\
\hline \multirow[t]{2}{*}{$\begin{array}{l}\text { Total assets } \\
\text { _GCAS }\end{array}$} & $\begin{array}{l}\text { Correlation } \\
\text { of Pearson }\end{array}$ & $\begin{array}{r}, 774^{*} \\
* \\
\end{array}$ &, $728^{* *}$ &, $553^{* *}$ & ,991** &, $768^{* *}$ &, $754^{* *}$ & ,275 & ,991* &, $591^{* *}$ &, $402^{* *}$ & ,671 $1^{* *}$ &,- 052 &, $343^{*}$ \\
\hline & Sig. &, 000 & ,000 & ,000 & ,000 & , 000 & ,000 & ,068 & ,000 & ,000 & ,006 & ,000 & ,733 &, 021 \\
\hline $\begin{array}{l}\text { Permanent } \\
\text { funding }\end{array}$ & $\begin{array}{l}\text { Correlation } \\
\text { of Pearson }\end{array}$ & $\begin{array}{r}983^{*} \\
* \\
\end{array}$ & , 159 &, $570^{* *}$ &, $756^{* *}$ &, $977 * *$ & , 196 &, $397^{* *}$ &, $755^{* *}$ &, $739^{* *}$ &,- 184 &, $483^{* * *}$ &,- 093 &, $474^{* *}$ \\
\hline _GCAS & Sig. & ,000 & ,296 & , 000 & , 000 & ,000 & , 197 & 007 & ,000 & ,000 & ,227 & ,001 & ,543 & ,001 \\
\hline $\begin{array}{l}\text { Current } \\
\text { liabilities }\end{array}$ & $\begin{array}{l}\text { Correlation } \\
\text { of Pearson }\end{array}$ & ,173 & ,988 & ,202 &, $760^{* *}$ & , 178 &, $995 * *$ &,- 094 &, $760^{* *}$ & ,073 & $808^{* *}$ &, $530^{* *}$ &,- 021 &,- 044 \\
\hline _GCAS & Sig. & ,255 & ,000 & ,184 & ,000 & ,243 & ,000 &, 541 & ,000 & ,635 & ,000 & ,000 & 889 & ,774 \\
\hline \multirow[t]{2}{*}{$\begin{array}{l}\text { Treasury } \\
\text { _GCAS }\end{array}$} & $\begin{array}{l}\text { Correlation } \\
\text { of Pearson }\end{array}$ & $\begin{array}{r}428^{*} \\
*\end{array}$ & ,013 &, $656^{* *}$ &, $315^{*}$ &, $390^{* *}$ &,- 007 &, $856 * *$ &, $320^{*}$ &, $784^{* *}$ & ,069 &, $308^{*}$ & ,195 &, $728^{* *}$ \\
\hline & Sig. & ,003 & ,934 & ,000 & ,035 & ,008 & ,964 & ,000 & ,032 & ,000 & ,654 & ,039 & , 199 & ,000 \\
\hline \multirow[t]{2}{*}{$\begin{array}{l}\text { Total liabilities } \\
\text { _GCAS }\end{array}$} & $\begin{array}{l}\text { Correlation } \\
\text { of Pearson }\end{array}$ & $\begin{array}{r}774^{*} \\
*\end{array}$ & ,728** &, $553^{* *}$ & ,991** &, $769^{* *}$ &, $754^{* *}$ & ,274 & ,991** &, $591^{* *}$ &, $402^{* *}$ & ,671 ${ }^{* *}$ &,- 056 &, $343^{*}$ \\
\hline & Sig. & ,000 & ,000 & ,000 & ,000 & , 000 & ,000 & ,069 & ,000 & ,000 & ,006 & ,000 & ,717 & ,021 \\
\hline \multirow[t]{2}{*}{$\begin{array}{ll}\text { Net profit } \\
\text { _GCAS }\end{array}$} & $\begin{array}{l}\text { Correlation } \\
\text { of Pearson }\end{array}$ & $\begin{array}{r}651^{*} \\
*\end{array}$ & ,087 & $894^{* *}$ &, $520^{* *}$ &, $612^{* *}$ & ,118 &, $702^{* *}$ &, $519^{* *}$ &, $999 * *$ &,- 041 &, $309^{*}$ &,- 125 &, $865^{* *}$ \\
\hline & Sig. & ,000 &, 571 & ,000 & ,000 & , 000 & ,440 & ,000 & ,000 & ,000 & ,791 & ,039 & ,412 & ,000 \\
\hline \multirow[t]{2}{*}{$\begin{array}{l}\text { Debt } \\
\text { _GCAS }\end{array}$} & $\begin{array}{l}\text { Correlation } \\
\text { of Pearson }\end{array}$ &,- 177 &, $897^{* *}$ & ,010 &, $468^{* *}$ &,- 173 &, $866^{* *}$ &,- 044 &, $470^{* *}$ &,- 141 &, $\mathbf{8 2 0} * *$ & $307^{*}$ & ,172 &,- 209 \\
\hline & Sig. & ,245 & ,000 & ,948 & ,001 & ,255 & ,000 & ,772 & ,001 & ,354 & ,000 & ,040 &, 257 & , 168 \\
\hline \multirow[t]{2}{*}{$\begin{array}{ll}\text { Current ratio } \\
\text { _GCAS }\end{array}$} & $\begin{array}{l}\text { Correlation } \\
\text { of Pearson }\end{array}$ &,- 109 & ,061 & ,057 &,- 025 &,- 117 & ,069 &,- 020 &,- 026 & ,057 & ,015 &,- 142 &,- 249 &, 043 \\
\hline & Sig. & ,476 & ,689 & ,710 & ,872 & ,442 & ,653 & 896 & 867 & ,710 & ,921 & ,353 & ,099 & ,779 \\
\hline $\begin{array}{l}\text { Investor } \\
\text { Investment }\end{array}$ & $\begin{array}{l}\text { Correlation } \\
\text { of Pearson }\end{array}$ &,- 284 &,- 116 &,$- 310^{*}$ &,- 275 &,- 283 &,- 194 & ,278 &,- 269 &,- 241 &,- 046 &,- 202 &, $602 * *$ &,$- 353^{*}$ \\
\hline Ratio_GCAS & Sig. & ,058 & ,450 & ,038 & ,067 & ,060 & ,201 & ,065 & ,074 &, 111 & ,765 & , 182 & ,000 & ,017 \\
\hline $\begin{array}{l}\text { Financial } \\
\text { profitability }\end{array}$ & $\begin{array}{l}\text { Correlation } \\
\text { of Pearson }\end{array}$ & ,290 &,- 110 &, $719^{* *}$ & ,154 & ,243 &,- 092 &, $657^{* *}$ &, 155 &, $775^{* *}$ & ,063 & ,268 &,- 149 & ,931** \\
\hline _GCAS & Sig. & ,054 & 470 & ,000 & ,312 & ,107 & ,548 & ,000 & ,311 & ,000 & 679 & ,076 & ,329 & ,000 \\
\hline
\end{tabular}

**. The correlation is significant at the 0.01 level (bilateral).

*. The correlation is significant at the 0.05 level (bilateral). 


\section{Macrothink \\ International Journal of Accounting and Financial Reporting \\ ISSN 2162-3082 \\ 2017, Vol. 7, No. 2}

Table 2. Correlation between the IFRS and GCAS variables 2012-2016

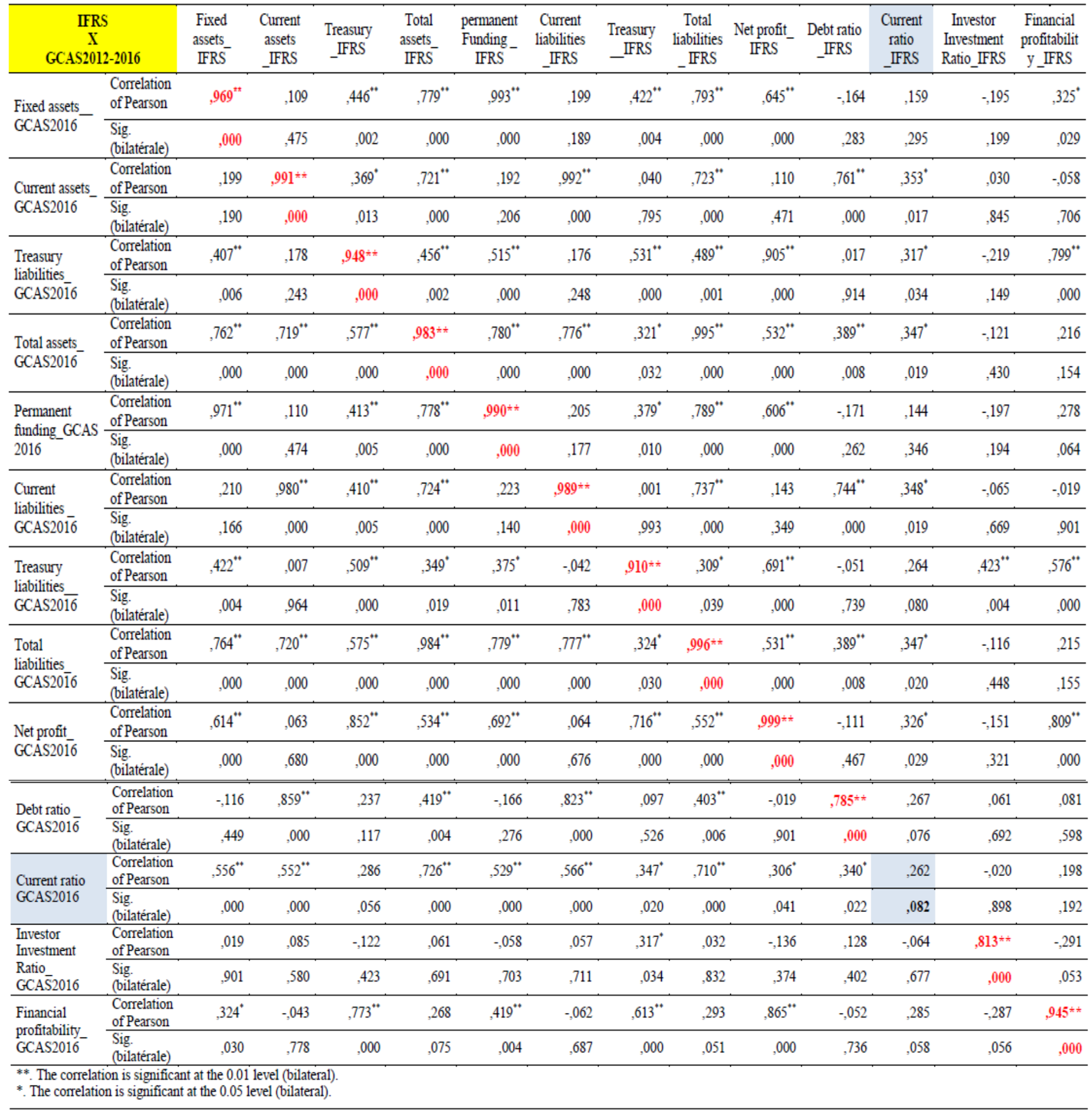




\section{MlMacrothink \\ International Journal of Accounting and Financial Reporting \\ ISSN 2162-3082 \\ 2017, Vol. 7, No. 2}

Table 3. Correlation between GCAS2007-2011 and IFRS variables

\begin{tabular}{|c|c|c|c|c|c|c|c|c|c|c|c|c|c|c|}
\hline \multicolumn{2}{|c|}{$\begin{array}{l}\text { Correlations : } \\
\text { GCAS2007-2011 } \\
\text { X } \\
\text { IFRS }\end{array}$} & \multirow{2}{*}{$\begin{array}{l}\begin{array}{c}\text { Fixed } \\
\text { assets_ } \\
\text { IFRS }\end{array} \\
, 960^{77}\end{array}$} & \multirow{2}{*}{$\begin{array}{r}\begin{array}{c}\text { Current } \\
\text { assets } \\
\text { IFRS } \\
, 111\end{array} \\
,\end{array}$} & \multirow{2}{*}{$\begin{array}{c}\begin{array}{c}\text { Treasury } \\
\text { _FRS }\end{array} \\
, 544^{\prime \prime}\end{array}$} & \multirow{2}{*}{$\begin{array}{r}\text { Total } \\
\text { assets_- } \\
\text { IFRS } \\
, 781^{\prime \prime}\end{array}$} & \multirow{2}{*}{$\begin{array}{c}\begin{array}{c}\text { permanent } \\
\text { funding } \\
\text { IFRS }\end{array} \\
, 992^{\prime \prime}\end{array}$} & \multirow{2}{*}{$\begin{array}{c}\begin{array}{c}\text { Current } \\
\text { liabilities } \\
\text { IFRS }\end{array} \\
, 201\end{array}$} & \multirow{2}{*}{$\begin{array}{c}\begin{array}{c}\text { Treasury } \\
\text { IFRS }\end{array} \\
, 460^{\prime \prime}\end{array}$} & \multirow{2}{*}{$\begin{array}{c}\begin{array}{c}\text { Total } \\
\text { liabiliti }\end{array} \\
\text { es } \\
\text { IFRS } \\
, 798^{\prime \prime \prime}\end{array}$} & \multirow[t]{2}{*}{$\begin{array}{c}\begin{array}{c}\text { Net } \\
\text { profit } \\
\text { IFRS }\end{array} \\
, 727^{\prime \prime}\end{array}$} & \multirow{2}{*}{$\begin{array}{r}\begin{array}{c}\text { Debt ratio } \\
\text { _IFRS }\end{array} \\
-, 162\end{array}$} & \multirow{2}{*}{$\begin{array}{c}\begin{array}{c}\text { Current } \\
\text { ratio } \\
\text { IFRS } \\
, 170\end{array} \\
\end{array}$} & \multirow{2}{*}{$\begin{array}{c}\begin{array}{c}\text { Investor } \\
\text { Investment } \\
\text { Ratio_IFRS }\end{array} \\
-, 219\end{array}$} & \multirow{2}{*}{$\begin{array}{c}\begin{array}{c}\text { Financial } \\
\text { profitabilit } \\
\text { y_IFRS }\end{array} \\
, 414^{\prime \prime}\end{array}$} \\
\hline $\begin{array}{l}\text { Fixed } \\
\text { assets_GCAS }\end{array}$ & $\begin{array}{l}\text { Correlation } \\
\text { of Pearson }\end{array}$ & & & & & & & & & & & & & \\
\hline & Sig. &, 000 &, 466 & 000 & 000 &, 000 & ,185 & 001 &, 000 &, 000 & 288 &, 265 &, 148 &, 005 \\
\hline \multirow[t]{2}{*}{$\begin{array}{l}\text { Current } \\
\text { assets_GCAS }\end{array}$} & $\begin{array}{l}\text { Correlation } \\
\text { of Pearson }\end{array}$ &, 113 & $989^{* \pi}$ &, $355^{\circ}$ & $657^{\prime \prime}$ & ,124 & $980^{\prime \prime}$ &,- 039 & $664^{\prime \prime}$ & ,068 &, $755^{\prime \prime}$ & $365^{\circ}$ &,- 014 &,- 074 \\
\hline & Sig. & 458 & ,000 & ,017 &, 000 & ,418 &, 000 & 800 &, 000 & 658 &, 000 & ,014 & ,930 &, 629 \\
\hline \multirow[t]{2}{*}{$\begin{array}{l}\text { Treasury } \\
\text { _GCAS }\end{array}$} & $\begin{array}{l}\text { Correlation } \\
\text { of Pearson }\end{array}$ &, $459^{\prime \prime}$ & 229 & $924^{* *}$ &, $520^{\prime \prime}$ &, $558^{\prime \prime}$ &, 226 &, $552^{\prime \prime}$ &, $548^{\prime \prime}$ & $914^{\prime \prime}$ & 046 & $339^{\circ}$ &,- 221 & $811^{\prime \prime}$ \\
\hline & Sig. &, 002 &, 130 & 000 & 000 &, 000 & , 136 & ,000 &, 000 &, 000 & ,765 &, 023 &, 145 &, 000 \\
\hline \multirow[t]{2}{*}{$\begin{array}{l}\text { Total assets } \\
\text { _GCAS }\end{array}$} & $\begin{array}{l}\text { Correlation } \\
\text { of Pearson }\end{array}$ &, $764^{\prime \prime}$ & $687^{*+}$ & $.652^{\prime+}$ & $971^{* *}$ &, $799^{\prime \prime}$ &, $744^{* 4}$ &, $330^{\circ}$ &, $989^{\circ+}$ & $604^{\prime \prime}$ & $345^{\circ}$ & $359^{\circ}$ &,- 177 & $295^{*}$ \\
\hline & Sig. & ,000 &, 000 &, 000 & 000 &, 000 & ,000 & ,027 &, 000 & ,000 &, 020 &, 015 &, 245 &, 049 \\
\hline \multirow{2}{*}{$\begin{array}{l}\text { Permanent } \\
\text { funding } \\
\text { GCAS }\end{array}$} & $\begin{array}{l}\text { Correlation } \\
\text { of Pearson }\end{array}$ &, $942^{\prime \prime}$ &, 105 & $.557^{\prime \prime}$ &, $766^{\prime \prime}$ & $990^{* *}$ & ,189 &, $443^{\prime \prime}$ &, $787^{\prime \prime}$ &, $736^{\prime \prime}$ &,- 168 & , 185 &,- 242 &, $421^{\prime \prime}$ \\
\hline & Sig. &, 000 & 492 &, 000 &, 000 & ,000 &, 213 &, 002 &, 000 &, 000 &, 270 & 224 & , 109 & 004 \\
\hline \multirow{2}{*}{$\begin{array}{l}\text { Current } \\
\text { liabilities } \\
\text { _GCAS }\end{array}$} & $\begin{array}{l}\text { Correlation } \\
\text { of Pearson }\end{array}$ & ,193 & $977^{*+}$ &, $376^{\circ}$ &, $706^{*+}$ & ,204 & $986^{* *}$ &,- 049 &, $718^{\prime \prime}$ & ,097 &, $724^{\prime \prime}$ & $337^{\circ}$ &,- 074 &,- 066 \\
\hline & Sig. &, 205 &, 000 & 011 &, 000 &, 179 &, 000 & ,749 &, 000 &, 525 &, 000 &, 023 & 629 & ,668 \\
\hline \multirow[t]{2}{*}{$\begin{array}{l}\text { Treasury } \\
\text { GCAS }\end{array}$} & $\begin{array}{l}\text { Correlation } \\
\text { of Pearson }\end{array}$ & $479^{\prime \prime}$ &, 021 & $621^{\prime \prime}$ & $404^{\prime \prime}$ &, $443^{\prime \prime}$ &,- 006 &, $837^{* *}$ &, $367^{\circ}$ & $788^{\prime \prime}$ &,- 090 & 290 &, 249 &, $720^{\prime \prime}$ \\
\hline & Sig. & ,001 & 890 &, 000 & 006 &, 002 & 967 & ,000 & , 013 &, 000 &, 558 &, 053 &, 100 &, 000 \\
\hline \multirow{2}{*}{$\begin{array}{l}\text { Total } \\
\text { liabilities_GC } \\
\text { AS }\end{array}$} & $\begin{array}{l}\text { Correlation } \\
\text { of Pearson }\end{array}$ &, $765^{\prime \prime}$ & $687^{\prime \prime}$ &, $652^{\prime \prime}$ & $971^{\prime \prime}$ & ,799" &, $744^{\prime \prime}$ & $329^{\circ}$ & $989^{* *}$ & $604^{\prime \prime}$ &, $344^{\circ}$ & $359^{\circ}$ &,- 178 & $295^{\circ}$ \\
\hline & Sig. &, 000 &, 000 &, 000 &, 000 &, 000 &, 000 &, 027 &, 000 &, 000 &, 021 & ,016 & ,241 & ,049 \\
\hline \multirow[t]{2}{*}{$\begin{array}{l}\text { Net profit } \\
\text { _GCAS }\end{array}$} & $\begin{array}{l}\text { Correlation } \\
\text { of Pearson }\end{array}$ &, $621^{\prime \prime}$ & $\overrightarrow{, 065}$ & $847^{\prime \prime}$ &, $540^{\prime \prime}$ &, $694^{\prime \prime}$ &, 064 &, $731^{\prime \prime}$ &, $555^{\prime \prime}$ & $999^{* *}$ &,- 114 & $325^{\circ}$ &,- 137 & $810^{\prime \prime}$ \\
\hline & Sig. &, 000 &, 671 &, 000 &, 000 &, 000 &, 675 &, 000 &, 000 &, 000 & 457 &, 029 & 368 &, 000 \\
\hline \multirow[t]{2}{*}{$\begin{array}{l}\text { Debt ratio } \\
\text { _GCAS }\end{array}$} & $\begin{array}{l}\text { Correlation } \\
\text { of Pearson }\end{array}$ &,- 123 & $909^{\prime \prime}$ &, 156 &, $435^{*+}$ &,- 151 & $869^{\prime \prime}$ &,- 051 & $422^{*+}$ &,- 121 &, $790^{* *}$ & $334^{\circ}$ &, 252 &,- 255 \\
\hline & Sig. & 421 &, 000 & ,307 &, 003 &, 323 &, 000 & ,738 &, 004 & 428 & ,000 &, 025 &, 095 &, 091 \\
\hline \multirow[t]{2}{*}{$\begin{array}{l}\text { Current ratio } \\
\text { _GCAS }\end{array}$} & $\begin{array}{l}\text { Correlation } \\
\text { of Pearson }\end{array}$ &,- 177 & 079 &,- 036 &,- 084 &,- 094 &, 003 &,- 016 &,- 067 & ,039 & ,107 & ,221 &,- 070 &,- 035 \\
\hline & Sig. & 246 & 605 & 813 &, 582 & ,541 & 982 & 919 & ,664 &, 798 &, 482 & ,144 & ,649 &, 822 \\
\hline \multirow{2}{*}{$\begin{array}{l}\text { Investor } \\
\text { Investment } \\
\text { Ratio_GCAS }\end{array}$} & $\begin{array}{l}\text { Correlation } \\
\text { of Pearson }\end{array}$ &,- 204 &,- 079 &,$- 332^{\circ}$ &,- 203 &,$- 315^{\circ}$ &,- 145 & 239 &,- 263 &,- 248 &, 006 &,- 129 &, $738^{* *}$ & $-360^{\circ}$ \\
\hline & Sig. & , 179 & 608 & , 026 & , 181 &, 035 &, 342 &, 114 &, 080 &, 100 &, 970 & ,398 & 000 &, 015 \\
\hline \multirow{2}{*}{$\begin{array}{l}\text { Financial } \\
\text { profitability } \\
\text { GCAS }\end{array}$} & $\begin{array}{l}\text { Correlation } \\
\text { of Pearson }\end{array}$ & ,276 &,- 108 & $643^{\prime \prime}$ & , 191 & $.323^{\circ}$ &,- 144 & $.693^{\prime \prime}$ &, 192 &, $775^{\prime \prime}$ &,- 128 & 243 &,- 165 & $939^{* *}$ \\
\hline & Sig. &, 066 & ,481 &, 000 & 210 & ,031 &, 346 &, 000 & 206 &, 000 & 403 &, 107 &, 279 &, 000 \\
\hline
\end{tabular}




\section{1ll Macrothink}

International Journal of Accounting and Financial Reporting

ISSN 2162-3082 2017, Vol. 7, No. 2

\section{GCAS 2006 - GCAS 2012_2016}

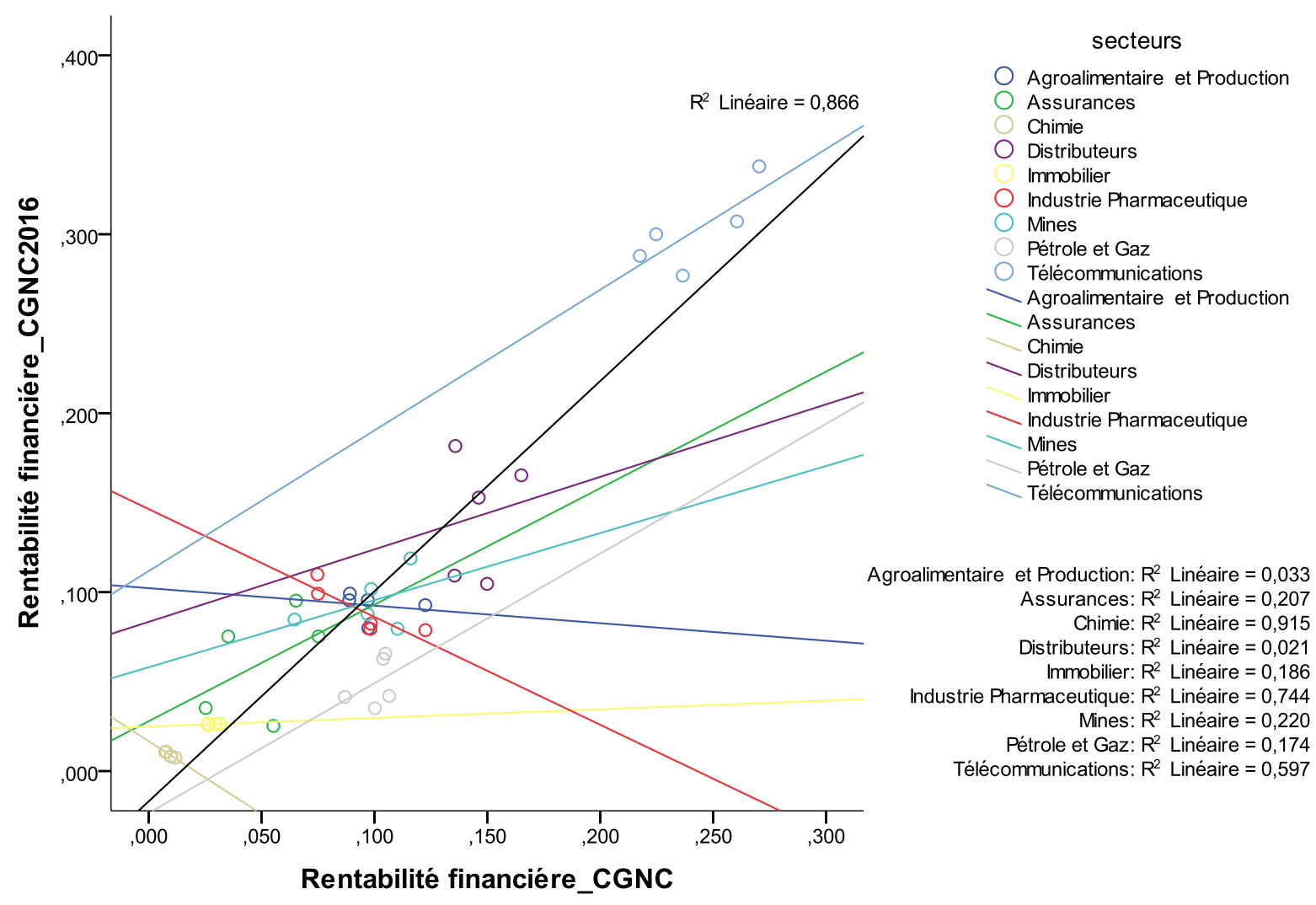

Figure 1. The relationship between the variable "Financial profitability" before and after the adoption of IFRS and by sector

The relationship between Financial profitability variables before and after IFRS is significant (correlation coefficient $=0.931, \mathrm{p}<0.01$ and $\mathrm{R}^{2}=0.866$ adjustment coefficient, Table 1 , Figure 1). This is due to the strong activity that the Moroccan market experienced by its different sectors between the period 2007-2016, and this activity experienced a strong positive correlation after 2010. This is specifically true after the internationalization of Moroccan accounting and its opening to the world market.

However, this image is not generalized on all sectors of the Moroccan market, indeed some sectors have been negatively correlated such as Chemistry $\left(R=-0.852, R^{2}=0.915\right)$, food industry $\left(R=-0.574, R^{2}=0.033\right)$, and pharmaceutical industry $\left(R=-0.862, R^{2}=0.744\right)$, due to the peculiarities of the components of the financial profitability formula which gave a quasi-same impact on the Net Result variable.

It is also noted that the values of the Net Result variable of the telecommunication sectors are the most representative, which is due to the high value of trade in this sector. 


\section{GCAS2006 - IFRS}

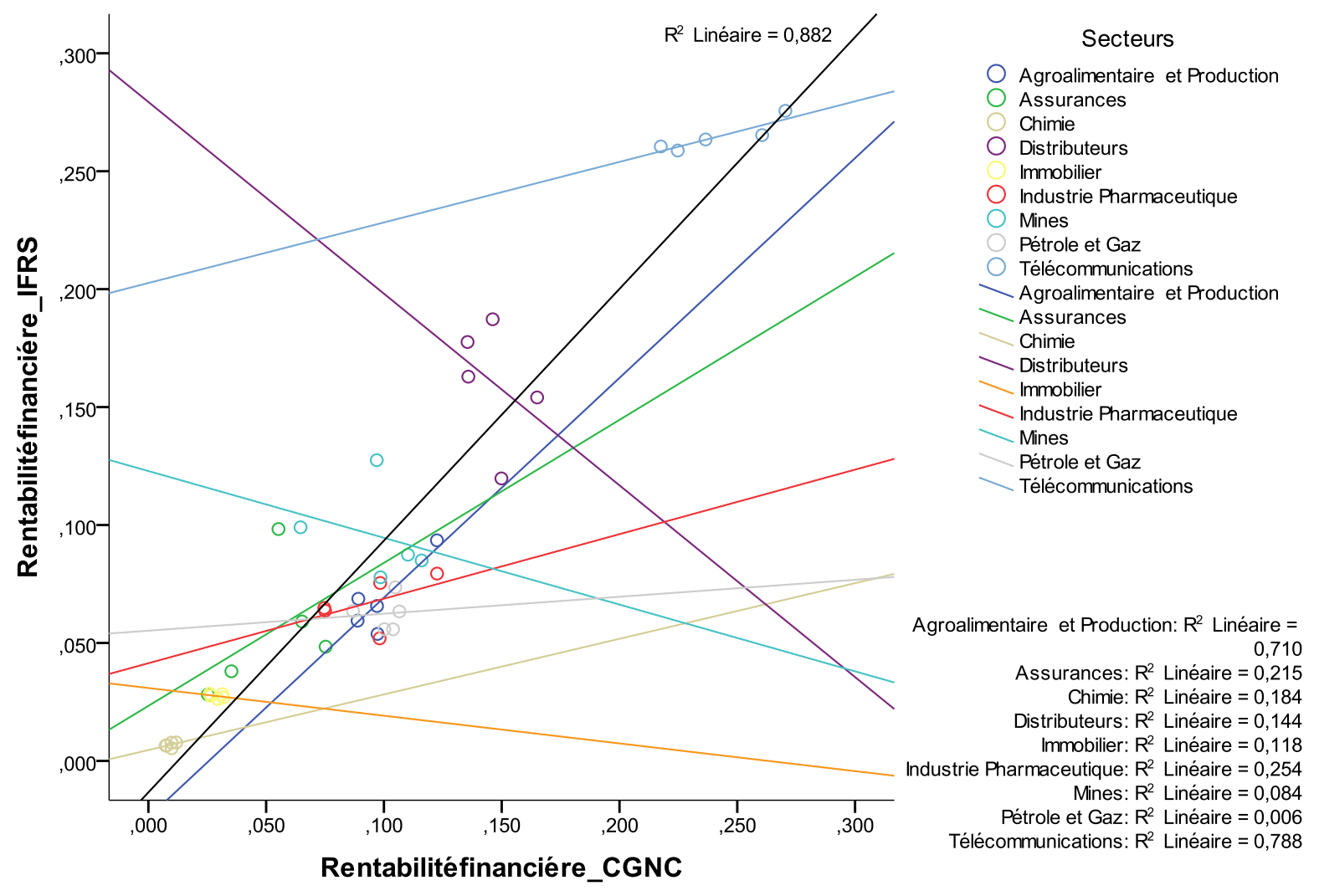

Figure 2. The relationship between the financial profitability variable between GCAS2006 and IFRS and by sector

It should be noted that the relationship between GCAS's financial profitability before IFRS adoption and IFRS is significant (correlation coefficient 0.939, p <0.01 and adjusted coefficient of determination $\mathbf{R}^{2}=0.882$, Table 2, Figure 2). This is logical and normal, due to the changing activity that the Moroccan market experienced by its various sectors after the adoption of IFRS, and this activity has been more positively correlated after the adoption of IFRS. This is specifically true after the internationalization of Moroccan accounting and its opening to the world market. However, this image is not generalized in all sectors of the Moroccan market, as certain sectors have been negatively correlated, such as the distributors, mining, and real estate sectors, which is due to the particularities of the components of the Profitability in these sectors.

We also find that the values of the financial return variable in certain sectors such as food industry, are the most representative, which is due to the high importance of financial profitability in these sectors.

Strong relationships for financial profitability are presented by all other sectors, the most important being those of telecommunications. 
IFRS vs. GCAS2012_2016
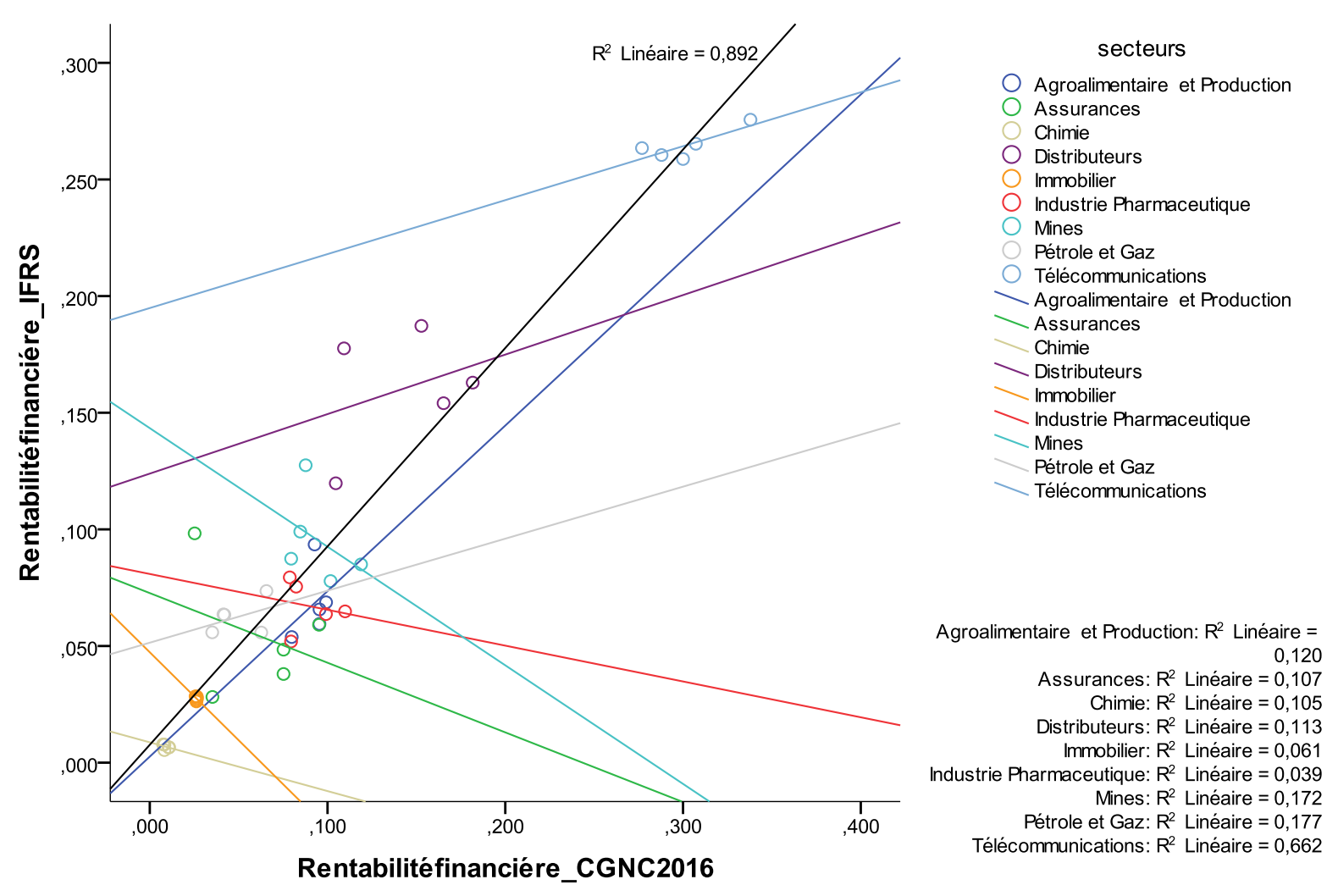

Figure 3. The relationship between the financial profitability variable between GCAS2016 and IFRS and by sector

The relationship between GCAS's financial profitability and IFRS is significant (correlation coefficient 0.944, $\mathrm{p}<0.01$ and adjusted coefficient of determination R2 $=0.892$, Table 3 , Figure 3). This is logical and normal, due to the changing activity that the Moroccan market experienced by its various sectors after the adoption of IFRS, and this activity has been more positively correlated after the adoption of IFRS. This is specifically true after the internationalization of Moroccan accounting and its opening to the world market. However, this image is not generalized across all sectors of the Moroccan market, indeed some sectors have been negatively correlated, such as the insurance, pharmaceutical, mining and real estate sectors which is due the particularities of the components of financial profitability in those sectors.

We also find that the values of the financial return variable in certain sectors are the most representative, which is due to the high importance of financial profitability in its sectors.

Strong relationships for financial profitability are presented by all other sectors, the most important being those of telecommunications. 


\section{Ml Macrothink}

International Journal of Accounting and Financial Reporting ISSN 2162-3082

In order to reduce the factors influencing our variables and to visualize the main common components that regroups the different variables, We recall the statistical function of the Principal Component Analysis (Figure 4).

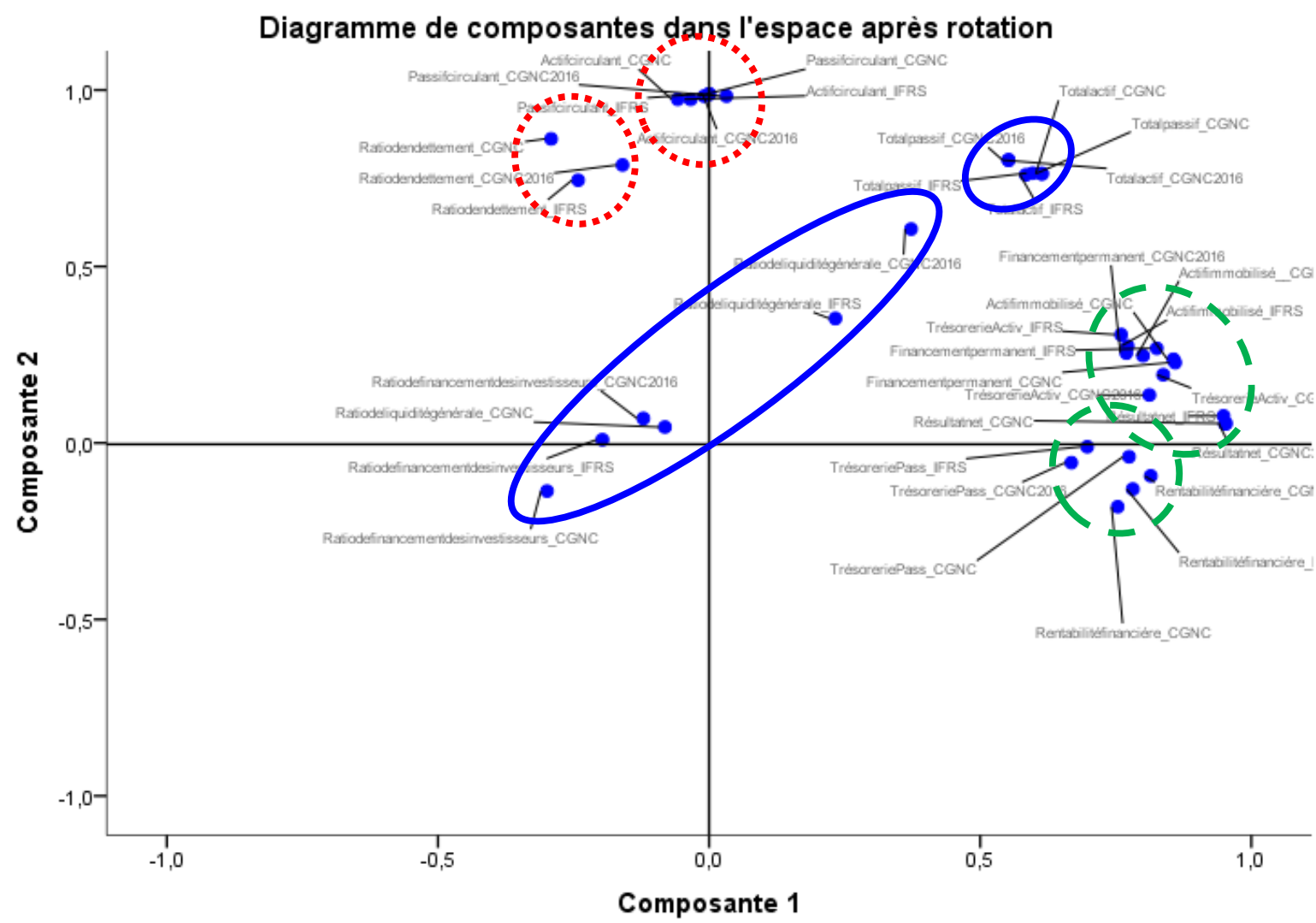

Figure 4. Analysis of principal components of accounting and financial variables (GCAS2007, GCAS2016, IFRS)

The general liquidity ratio before the adoption of IFRS is not correlated either with that of IFRS or with GCAS after the adoption of the IFRS, which is normal because after the adoption of the IFRS the lower transactions to one year experienced remarkable variability due to the phenomenon of globalization. This leads us to ask several reflections on the quality of correlation between different variables and between different references and periods. Indeed, there is a concentration of variables Total Assets, Total Liabilities, Financial Profitability, Permanent Financing; Fixed assets; Active Treasurer; Treasurer Liabilities and Net Income on Component 1 and concentration of variables Current assets; Passive flow; and Debt Ratio on Component 2. 
Rentabilitéfinanciére_CGNC

Rentabilitéfinanciére_IFRS

Rentabilitéfinanciére_CGNC2016

Ratiodendettement_CGNC

Ratiodendettement_CGNC2016

Ratiodendettement_IFRS

Ratiodefinancementdesinvestisseurs_CGNC2016

Ratiodefinancementdesinvestisseurs_IFRS

Ratiodefinancementdesinvestisseurs_CGNC

Ratiodeliquiditégénérale_CGNC2016

Ratiodeliquiditégénérale_IFRS

Ratiodeliquiditégénérale_CGNC

TrésoreriePass_CGNC2016

TrésoreriePass_IFRS

TrésoreriePass_CGNC

Résultatnet_CGNC2016

Résultatnet_IFRS

Résultatnet_CGNC

TrésorerieActiv_CGNC

$>$ TrésorerieActiv_CGNC2016

TrésorerieActiv_IFRS

Actifcirculant_CGNC

Passifcirculant_CGNC

Actifcirculant_CGNC2016

Passifcirculant_CGNC2016

Passifcirculant_IFRS

Actifcirculant_IFRS

Actifimmobilisé_CGNC2016

Financementpermanent_CGNC2016

Financementpermanent_IFRS

Actifimmobilisé_CGNC

Financementpermanent_CGNC

Actifimmobilisé_IFRS

Totalactif_CGNC

Totalpassif_CGNC

Totalactif_CGNC2016

Totalpassif_CGNC2016

Totalpassif_IFRS

Totalactif_IFRS

Arbre hiérarchique utilisant la Distance moyenne (entre classes)

Distance de combinaison des classes redimensionnée

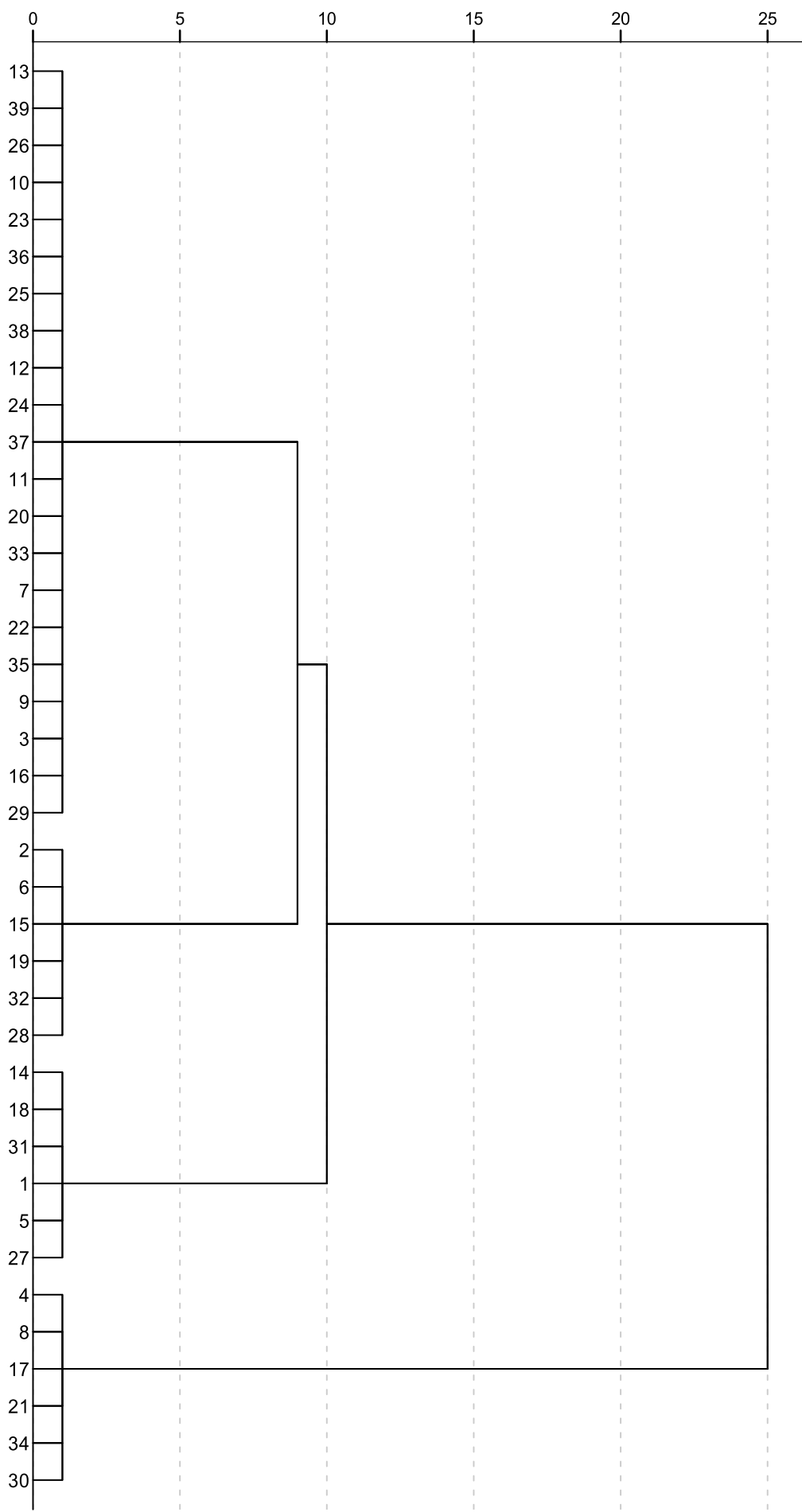

Figure 5. Hierarchical Analysis of Accounting and Financial Variables (GCAS2007, GCAS2016, IFRS) 


\section{Mll Macrothink}

International Journal of Accounting and Financial Reporting

ISSN 2162-3082

2017, Vol. 7, No. 2

To verify our hypothesis, after the correlation matrices, the graphical representations between each variable, each sector and each referential and after the PCA which groups the different graphs to visualize the reconciliation (grouping / classification) of these different variables (Figure 4) to measure the mean distances between the different classes of variables, which confirmed the results of the PCA.

The variables "total active" and "total passive" belong to a single class. A second class regroups the variables "fixed asset" and "permanent financing". The 3rd class regroups the variables: active circulating and passive circulating. The 4th class includes: "cash assets and liabilities", "net income" and all variables of financial information.

\section{References}

Ahsina, K., Taouab, O., \& Cherqaoui, M.B. (2014). L'impact de l'adoption des IFRS sur les sociétés cotées à la bourse de Casablanca: une étude exploratoire. Rev. Gest. Organ. 6, 75-83. https://doi.org/10.1016/j.rgo.2014.09.003

Cherti, A., \& Zaam, H. (2016). IFRS Adoption Impact on Financial And Accounting Information Quality: An Exploratory Study On Moroccan Petroleum And Gas Sector. Bus. Econ. Res. 6, 337-351. https://doi.org/10.5296/ber.v6i1.9184

Gavard-Perret, M.-L., Gotteland, D., Haon, C., \& Jolibert, A. (2012). Méthodologie de la recherche en sciences de gestion: Réussir son mémoire ou sa thèse. Pearson Education France.

Hallouët, P. (2016). FICHE 184 - Analyse de résultats de recherche. Utilisation de méthodes statistiques. In Méga Mémo IFSI (2e édition). Elsevier Masson, Paris, pp. 1259-1264.

Haoudi, K. (2015). Transition to IFRS in Morocco: Theoretical Foundations, benefits and issues. Int. J. Innov. Appl. Stud., 10, 1299-1311.

Palea, V. (2013). IAS/IFRS and financial reporting quality: Lessons from the European experience. China J. Account. Res. 6, 247-263. https://doi.org/10.1016/j.cjar.2013.08.003

Raymond-Alain, T. (2017). Méthodes de recherche en management.

Zehri, F., \& Chouaibi, J. (2013). Adoption determinants of the International Accounting Standards IAS/IFRS by the developing countries. J. Econ. Finance Adm. Sci. 18, 56-62. https://doi.org/10.1016/S2077-1886(13)70030-1

\section{Copyright Disclaimer}

Copyright for this article is retained by the author(s), with first publication rights granted to the journal.

This is an open-access article distributed under the terms and conditions of the Creative Commons Attribution license (http://creativecommons.org/licenses/by/4.0/) 